\title{
Etiology and prognosis of penetrating eye injuries in geriatric patients in the Southeastern region of Anatolia Turkey
}

\author{
Harun Yüksel, M.D., Fatih Mehmet Türkcü, M.D., Yasin Çınar, M.D., \\ Abdullah Kürşat Cingü, M.D., Alparslan Şahin, M.D., Muhammed Şahin, M.D., \\ Zeynep Özkurt, M.D., Mehmet Murat, M.D., İhsan Çaça, M.D.
}

Department of Ophthalmology, Dicle University Faculty of Medicine, Diyarbakir

\begin{abstract}
BACKGROUND: The purpose of this study was to evaluate the etiologic and prognostic factors of open eye injuries in geriatric patients in the Southeastern region of Anatolia.

METHODS: Forty-five geriatric patients who underwent surgery for an open eye injury in our clinic between the years of 2008 and 2012 were evaluated retrospectively. Age, gender, cause and the mechanism of the trauma, visual acuity (VA), and the time between the trauma and the surgery were obtained from files and evaluated.

RESULTS: The mean age of the patients was 70.4 \pm 8.2 (65-90) years. Thirty-four of the cases were male and II were female. The most frequent mechanism of trauma was a wood strike, while the second most common one was injury with a knife. Corneoscleral penetration was the most frequently observed trauma. The mean VA of the patients was $2.26 \pm 0.65$ at admission, and was I.53 \pm 0.99 logarithm of the minimum angle of resolution at the final evaluation. The most frequent complications of trauma were iris prolapse and hyphema. There was a significant correlation between the first and final VA.
\end{abstract}

CONCLUSION: Penetrating ocular injuries are seen less frequently among geriatric patients, and their prognosis may be worse due to less-efficient wound site healing and differences in scleral rigidity. The most important factor affecting the final VA measurement was the VA of the patient at admission.

Key words: Eye; geriatric; injury.

\section{INTRODUCTION}

Ocular traumas, especially penetrating injuries, are among the most common causes of preventable vision loss. ${ }^{[1]}$ Ocular traumas constitute $7 \%$ of all bodily injuries and $10-15 \%$ of all eye diseases. ${ }^{[2,3]}$ Ocular traumas are a public health problem, which brings an important functional, medical, and socioeconomic burden; they are important because of their preventable character. ${ }^{[4]}$ Ocular penetrating traumas are most fre-

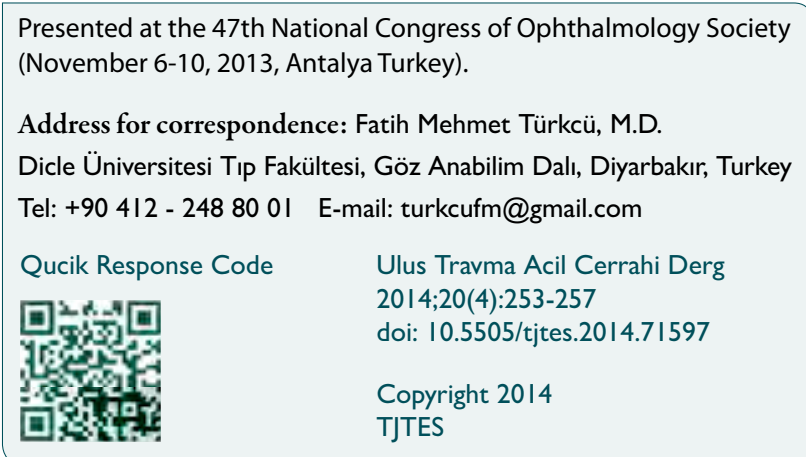

quently seen in children and adolescent patients. ${ }^{[5]}$ Therefore, there is a limited number of studies regarding ocular traumas in geriatric patients. ${ }^{[6,7]}$

Factors affecting the prognosis of ocular penetrating injuries have been previously reported. Factors such as advanced age, poor initial visual acuity (VA), type and extent of the injury, presence of vitreous hemorrhage and/or retinal detachment were reported to negatively affect the prognosis. ${ }^{[8-10]}$ However, there is limited information about factors affecting prognosis in geriatric cases. ${ }^{[6,7]}$

In this study, we aimed to investigate the causes of ocular penetrating injuries as well as features, and factors affecting prognosis in geriatric cases.

\section{MATERIALS AND METHODS}

Forty-five geriatric patients ( $\geq 65$ years of age) who underwent surgery for an open eye injury at Dicle University's Faculty of Medicine, Departments of Ophthalmology, between the years of 2008 and 2012 were evaluated retrospectively. 
Table I. Cause of ocular trauma in geriatric patients

\begin{tabular}{lcc}
\hline & $\mathbf{n}$ & $\%$ \\
\hline Wood & 16 & 35.6 \\
Knife & 8 & 17.8 \\
Fall & 7 & 15.6 \\
Horn strike & 4 & 8.9 \\
Stone & 3 & 6.7 \\
Metallic object & 3 & 6.7 \\
Accident & 2 & 4.4 \\
Needle & 2 & 4.4 \\
Total & 45 & 100 \\
\hline
\end{tabular}

Approval for this study was received from the Local Ethical Committee.

Age, gender, best corrected visual acuity (BCVA) at first admission and follow-up examinations, the cause of injury, laterality, the location of the perforation, the time between the trauma and admission to our clinic, previous surgical operations, anterior and posterior segment findings were noted from patient records. Cases that had a $\geq 6$-month follow-up period were included in the study. BCVA at the last examination and other surgeries that took place during that period (vitrectomy, lensectomy with phaco-intraocular lens and evisceration) were recorded.

Injuries were classified as corneal, scleral, or corneoscleral according to the location of the perforation. Cases were divided into five groups according to the time between the trauma and admission to the clinic (0-12 hours, 12-24 hours, 24-48 hours, 48-72 hours, and more than 72 hours). We used the ocular trauma score (OTS) method for each patient, which is based on the birmingham eye trauma terminology system, during the classification of the mechanical trauma. ${ }^{[I]}$

The BCVA of the cases were evaluated with the Snellen Chart. BCVA were converted to the logarithm of the minimum angle of resolution (logMAR) for calculations.

All cases underwent primary suturation under general anesthesia. A 10/0 nylon suture was used for suturing the cornea and a 7/0 Vicryl (polyglactin 910) suture was used for the sclera.
Patients older than 65 years of age that had not undergone any previous eye surgery except for cataract surgery with a follow-up period of with for at least 6 months in our clinic were included in the study.

\section{Statistical Analysis}

Data were presented as arithmetical mean \pm standard deviation. Statistical analyses of quantitative data, including descriptive statistics and parametric/non-parametric comparisons, were performed for all variables. Frequency analyses were performed with a chi-square test.

Multiple logistic analyses were performed in order to determine the combinations of clinical factors related to ocular trauma that predict the final BCVA. The multivariate model included factors found by univariate analyses to be significant predictors of final visual outcome $(p \leq 0.05$, univariate analysis). Statistical analyses were performed with the Statistical Package for the Social Sciences version 15.0 (SPSS Inc., Chicago, IL, USA) software. $\mathrm{P}<0.05$ was considered to be statistically significant.

\section{RESULTS}

Thirty-four (75.3\%) of the included cases were male and II (24.7\%) were female. Twenty-three cases (5I.1\%) injured the right eye and 22 cases (48.9\%) injured the left eye. The mean age of the patients was $70.4 \pm 8.2(65-90)$ years. The average follow-up period was $7.9 \pm 2.9$ (6-17) months.

Traumas were caused by blunt objects in $66.7 \%$ of the patients. The most common trauma was caused by a wood strike, and the second most common one was caused by a knife touch (Table I).

The majority of the penetrating injuries was corneoscleral $n=22(48.9 \%)$, followed by scleral $n=13(28.9 \%)$ and corneal $\mathrm{n}=10(22.2 \%)$ injuries.

The mean BCVA was 2.19 \pm 0.68 logMAR at admission and was $1.53 \pm 0.99 \log M A R$ at the 6th month of the follow-up (Table 2). The BCVA at admission was I.30 logMAR in II cases; at hand motion level in 21 cases, and at light perception level in 13 cases. The BCVA at the 6th month follow-up was I.30 logMAR in 29 cases, at hand motion level in six cases, and at light perception level in 10 cases.

Table 2. Initial uncorrected and final best corrected visual acuity of patients in the study

\begin{tabular}{lcccc}
\hline & Corneal injuries $(\mathbf{n}=1 \mathbf{0})$ & Corneoscleral injuries $(\mathbf{n = 2 2})$ & Scleral injuries $(\mathbf{n}=\mathbf{1 3})$ & $\mathbf{p}$ \\
\hline Initial BCVA (logMAR) & $2.24 \pm 0.67$ & $2.26 \pm 0.72$ & $2.03 \pm 0.64$ & 0.690 \\
Final BCVA (logMAR) & $1.57 \pm 0.99$ & $1.80 \pm 1.03$ & $1.06 \pm 0.81$ & 0.074 \\
\hline
\end{tabular}

logMAR: Logarithm of the minimum angle of resolution; BCVA: Best corrected visual acuity. 
OTS scores were one in $24(53.3 \%)$ patients, two in six (13.3\%) patients, three in 12 (26.7\%) patients and four in three $(6.7 \%)$ patients.

The majority (44.4\%) of the patients applied to our clinic within 24-48 hours of the trauma. The earliest admission occurred within I hour after the trauma, and the latest admission was 72 hours after the trauma (Table 3).

Associated findings with ocular penetrations are presented in Table 4. The most common preoperative examination findings were iris prolapse and hyphema.

The most common complications during the follow-up visit

Table 3. The time between the trauma and admission to the clinic

\begin{tabular}{lcc}
\hline Hours & $\mathbf{n}$ & $\%$ \\
\hline $0-12$ & 8 & 17.8 \\
$12-24$ & 11 & 24.4 \\
$24-48$ & 20 & 44.4 \\
$48-72$ & 1 & 2.2 \\
After 72 & 5 & 11.1 \\
Total & 45 & 100 \\
\hline
\end{tabular}

Table 4. Anterior and posterior segment findings at the time of admission

\begin{tabular}{lcc}
\hline & $\mathbf{n}$ & $\%$ \\
\hline Iris prolapse & 19 & 42.2 \\
Hyphema & 10 & 22.2 \\
Vitreous at the wound & 3 & 6.7 \\
Endophthalmitis & 3 & 6.7 \\
Cataract & 2 & 4.4 \\
Foreign body & I & 2.2 \\
Traumatic evisceration & I & 2.2 \\
Retinal detachment & I & 2.2 \\
Lens drop & I & 2.2 \\
Anterior chamber foreign body & I & 2.2 \\
\hline
\end{tabular}

Table 5. Associated surgeries during the follow-up period

\begin{tabular}{lcc}
\hline & $\mathbf{n}$ & $\%$ \\
\hline Cataract surgery (Phaco-IOL) & 14 & 31.1 \\
Pars plana vitrectomy & 7 & 15.6 \\
Evisceration & 3 & 6.7 \\
\hline
\end{tabular}

IOL: Intraocular lens. were cataracts and retinal detachment. The most frequent surgery undergone during the follow-up period was cataract surgery (Table 5).

Twenty-six cases (57.8\%) had already undergone cataract surgery at the time of admission. There was no statistically significant difference in location of the penetrating injury between the phakic and pseudophakic eyes $(p=0.510)$.

Correlation analysis revealed a negative correlation between age and first BCVA $(p=0.048 r=0.296)$ and between first and final BCVA $(p<0.001, r=0.766)$. Linear regression analysis revealed that the initial $B C V A$ was the only variable to significantly affect final BCVA $(p=0.008, R 2=0.592)$.

A chi-square test revealed that presence of hyphema, iris prolapse, or cataracts were not different between the patients who had 0.1 or higher BCVA and others at the time of admission.

\section{DISCUSSION}

Ocular trauma is one of the leading causes of unilateral preventable visual impairment and loss in the world. Especially in the pediatric age group the most important cause of unilateral visual impairment is ocular trauma. ${ }^{[5,12]}$ Recovery from penetrating eye injuries in geriatric cases is different from that of other age groups. ${ }^{[6,7]}$ In this study, we evaluated the factors affecting prognosis of penetrating eye injuries in geriatric cases.

It has been reported that males are more frequently affected by ocular traumas (72-95\% frequency)..$^{[1,5,8,13]}$ However, one study reported that the male:female ratio for geriatric cases is $1: I$, while another study reported that female cases were more frequent. ${ }^{[6,7]}$ In our study, we found that the male exposure rate was $75.3 \%$, which is compatible with data from other age groups.

In a study of geriatric cases by Tök et al., ${ }^{[6]}$ the mean age of the patients was $73.06 \pm 5.99$ years and in a study by Andreoli et al., ${ }^{[7]}$ it was 79.8 years. In our study, the mean age was $70.4 \pm 8.2(65-90)$ years. Several studies have reported that the right eye is most often affected, but some other studies have reported that trauma occurs most often in the left eye. $[1,5,14,15]$ In this study, there was no significant difference in the exposure rate of trauma between the right (5I.1\%) and left (48.9\%) eyes.

Animal breeding and agriculture are among the most important sources of income in the Southeastern region of Anatolia. Because of this, most of the documented traumas are due to wood and horn strike. In our study, ruptured, open eye injuries were seen most commonly seen, consistent with previous reports. ${ }^{[6,7]}$ Eye traumas due to falls were reported at a rate of $65 \%$ by Andreoli et al., ${ }^{[1]}$ and 15.6\% by Tök et al., ${ }^{[2]}$ but in our study, the rate was just $13.4 \%$. 
Corneal injuries are the most common eye injury in the nongeriatric population, while corneoscleral injuries are the most common in the geriatric population. Reasons for this include increased scleral rigidity and increased blunt trauma rates in older persons. ${ }^{[6,7]}$ In our study, we observed scleral or corneoscleral injury in $77.8 \%$ of cases. A great majority of them were ruptures caused by blunt traumas. In those cases, BCVA was found to be below hand motion in 15 cases (93.8\%) in patients with rupture and in one case $(6.2 \%)$ with penetrating trauma.

It has been reported that visual prognosis is worse for geriatric cases than those in the younger population. ${ }^{[6,7]}$ Several factors affect the visual prognosis for all age groups. It has been accepted that the most important factors are age and VA at admission..$^{[8,9,14,15]}$ In our study, we observed that BCVA at admission was at the level of counting fingers or less in $75.6 \%$ of cases. This ratio was reduced to $33.3 \%$ at the 6 months postoperatively. The worst prognosis was observed for those with corneoscleral injuries. Among all factors, only age and BCVA at admission were correlated with final BCVA. Multivariate analysis showed that the only factor that affects final BCVA is BCVA at admission. In contrast to our results, Tök et al., ${ }^{[6]}$ showed that there was a correlation between final BCVA and age, but did not show a correlation between final BCVA and BCVA at admission.

In this study, OTS in $53 \%$ of the patients was one and that value was consistent with BCVA at postoperative month 6 .

In previous studies, the endophthalmitis rate after penetrating traumas was reported to be $0.9-12 \%$ for all age groups. ${ }^{[16-18]}$ Endophthalmitis has not been previously reported in geriatric cases. Endophthalmitis occurred in three cases in our study, all of which were injured by organic substances. Previous studies have reported that the average time between the trauma and surgery was within the first 24 hours, but in our study, this time was within the first 48 hours. We hypothesize that this increased time between the trauma and the surgery causes an increased risk for endophthalmitis. Previous studies have shown that each day between the trauma and the surgery decreases BCVA 1.16-fold. ${ }^{[9]}$ Traumas occurred at home in $76 \%$ of the cases in a study by Andreoli et al., ${ }^{[7]}$ but in our study, traumas occurred mostly outdoors, and especially in the countryside. This may be another cause for an increased risk of endophthalmitis.

The intraocular foreign body (FB) rate in geriatric cases has been reported as $1 \% .{ }^{[7]}$ In our study, we observed FB in the vitreous cavity in one case and in the anterior chamber in another case, and an intraocular lens drop in one case. In total, the rate in our study was $6.7 \%$ (three cases) which is significantly higher than those in other studies.

There was traumatic evisceration in one case at admission. That patient underwent primary suturation; however, phthi- sis occurred during the follow-up, so we performed an evisceration. There were also two other patients that underwent evisceration. In this study by Tök et al., ${ }^{[6]}$ there were three eviscerations out of 30 cases. There is a lower evisceration rate for geriatric cases, which can be explained by their lowered esthetic concerns.

The most common surgical procedures performed during the follow-up were cataract extraction and vitrectomy. The increased rate of cataract surgery is most likely due to old age and the trauma. Vitrectomy was performed in seven cases during the follow-up because of retinal detachment. To the best of our knowledge, there have been no previous reports regarding surgeries during follow-up in geriatric cases. However, there were reports on eviscerations. ${ }^{[6,7]}$ In these cases, early surgical procedures are important for visual prognosis and rehabilitation.

We did not observe any sympathetic ophthalmia. The literature reports that the incidence of sympathetic ophthalmia is $1-2 \%{ }^{[8,10,19]}$ We believe that we did not see any sympathetic ophthalmia in our cases since they underwent routine steroid therapy after surgery or follow-up period was relatively short.

Our results indicate that ocular penetrating injuries have a relatively bad prognosis in geriatric cases. We believe that any differences between our study and previous studies can be explained by regional differences. We detected that the most important factors affecting visual prognosis are age and VA at admission.

\section{Acknowledgement}

We are grateful to Dicle University DUBAP for their sponsorship for English editing of this manuscript.

Conflict of interest: None declared.

\section{REFERENCES}

1. Liggett PE, Pince KJ, Barlow W, Ragen M, Ryan SJ. Ocular trauma in an urban population. Review of 1132 cases. Ophthalmology 1990;97:581-4.

2. Maltzman BA, Pruzon H, Mund ML. A survey of ocular trauma. Surv Ophthalmol 1976;21:285-90. CrossRef

3. Hassett PD, Kelleher CC. The epidemiology of occupational penetrating eye injuries in Ireland. Occup Med (Lond) 1994;44:209-11. CrossRef

4. McGwin G Jr, Xie A, Owsley C. Rate of eye injury in the United States. Arch Ophthalmol 2005;123:970-6. CrossRef

5. Keklikci U, Celik Y, Cakmak SS, Sakalar YB, Unlu MK. Evaluation of perforating eye injuries by using cluster analysis. Ann Ophthalmol (Skokie) 2008;40:87-93.

6. Tök L, Yalçın Tök Ö, Özkaya D, Eraslan E, Sönmez Y, Örnek F, et al. Characteristics of open globe injuries in geriatric patients. Ulus Travma Acil Cerrahi Derg 2011;17:413-8. CrossRef

7. Andreoli MT, Andreoli CM. Geriatric traumatic open globe injuries. Ophthalmology 2011;118:156-9. CrossRef 
8. Rahman I, Maino A, Devadason D, Leatherbarrow B. Open globe injuries: factors predictive of poor outcome. Eye (Lond) 2006;20:1336-41.

9. Cruvinel Isaac DL, Ghanem VC, Nascimento MA, Torigoe M, KaraJosé N. Prognostic factors in open globe injuries. Ophthalmologica 2003;217:431-5. CrossRef

10. Rofail M, Lee GA, O’Rourke P. Prognostic indicators for open globe injury. Clin Experiment Ophthalmol 2006;34:783-6. CrossRef

11. Kuhn F, Morris R, Witherspoon CD, Mester V. The Birmingham Eye Trauma Terminology system (BETT). J Fr Ophtalmol 2004;27:206-10.

12. Salvin JH. Systematic approach to pediatric ocular trauma. Curr Opin Ophthalmol 2007;18:366-72. CrossRef

13. Türkcü FM, Yüksel H, Sahin A, Cingü K, Arı S, Cinar Y, et al. Demographic and etiologic characteristics of children with traumatic serious hyphema. Ulus Travma Acil Cerrahi Derg 2013;19:357-62. CrossRef

14. Altıntaş L, Altıntaş O, Yüksel N, Pirhan D, Ozkan B, Cağlar Y. Pattern of open eye injuries in northwest Turkey: a retrospective study. Ulus Travma Acil Cerrahi Derg 2011;17:334-9.

15. Soylu M, Sizmaz S, Cayli S. Eye injury (ocular trauma) in southern Turkey: epidemiology, ocular survival, and visual outcome. Int Ophthalmol 2010;30:143-8. CrossRef

16. Thompson WS, Rubsamen PE, Flynn HW Jr, Schiffman J, Cousins SW. Endophthalmitis after penetrating trauma. Risk factors and visual acuity outcomes. Ophthalmology 1995;102:1696-701. CrossRef

17. Reynolds DS, Flynn HW Jr. Endophthalmitis after penetrating ocular trauma. Curr Opin Ophthalmol 1997;8:32-8. CrossRef

18. Andreoli CM, Andreoli MT, Kloek CE, Ahuero AE, Vavvas D, Durand ML. Low rate of endophthalmitis in a large series of open globe injuries. Am J Ophthalmol 2009;147:601-608.e2.

19. Casson RJ, Walker JC, Newland HS. Four-year review of open eye injuries at the Royal Adelaide Hospital. Clin Experiment Ophthalmol 2002;30:15-8. CrossRef

\section{KLINIK ÇALIŞMA - ÖZET}

Güneydoğu Anadolu Bölgesi’ndeki geriatrik hastalarda delici göz yaralanmalarında etiyoloji ve prognoz

Dr. Harun Yüksel, Dr. Fatih Mehmet Türkcü, Dr. Yasin Çınar, Dr. Abdullah Kürşat Cingü,

Dr. Alparslan Şahin, Dr. Muhammed Şahin, Dr. Zeynep Özkurt, Dr. Mehmet Murat, Dr. İhsan Çaça

Dicle Üniversitesi Tıp Fakültesi, Göz Anabilim Dalı, Diyarbakır

AMAÇ: Güneydoğu Anadolu Bölgesi'nde yaşayan geriatrik hastalarda açık göz yaralanmasının etiyolojik faktörleri ve prognozu etkileyen faktörleri irdelemek.

GEREÇ VE YÖNTEM: 2008-20I2 yılları arasında kliniğimizde açık göz yaralanması nedeni ile ameliyat edilen ve takibi yapılan 65 yaş ve üstü 45 olgu geriye dönük olarak değerlendirildi. Dosya bilgilerinden olguların yaşı, cinsiyeti, travmanın oluş nedeni ve şekli, görme derecesi, travmanın oluş zamanı ile cerrahi arasında geçen süre değerlendirildi.

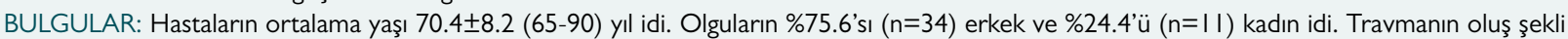
en sık olarak odun çarpması ve ikinci sıklıkta bıçak değmesi olarak tespit edildi. Korneaskleral penetrasyon en sık olarak izlendi. Görme keskinlikleri müracaat anında $2.26 \pm 0.65$ logMAR ölçüldü. Travmaya en sık eşlik eden komplikasyon iris prolapsusu ve hifema olarak izlendi. Illk görme keskinliği ile nihai görme keskinliği arasında korelasyon izlendi.

TARTIŞMA: Geriatrik olgularda oküler penetran yaralanmalar daha az görülmekle beraber yara yeri iyileşmesi zorluğu ve değişen skleral rijidite nedeniyle daha kötü prognozlu olabileceği düşünüldü. Nihai görme keskinliğini etkileyen en önemli faktörün hastanın müracaat anındaki görme keskinliği olduğu görüldü.

Anahtar sözcükler: Geriatri; göz; yaralanma.

Ulus Travma Acil Cerrahi Derg 20 I4;20(4):253-257 doi: 10.5505/tjtes.20।4.7I597 